\title{
Cutaneous lesions caused by the yellow fever vaccine - have you ever seen them?
}

1. Pontifical Catholic University of Rio Grande do Sul, Faculty of Medicine, Porto Alegre, RS, Brasil. 2. Health Surveillance Secretariat - Ministry of Health (SVS/MS), Brasilia, DF, Brasil

\section{SUMMARY}

The Yellow Fever virus was isolated in 1927 and the disease is considered endemic and epidemic in tropical regions of South America and Africa, with thousands of new cases reported annually. Several side effects of the vaccine have already been reported. Although reports of skin rash secondary to the vaccine range from 0 to $15 \%$, no image or detailed description of the lesions were found in the literature. Here we describe a rash on a toddler vaccinated to travel.

KEYWORDS: Exanthema. Drug eruptions. Adverse drug reaction reporting systems. Yellow fever vaccine.

\section{INTRODUCTION}

The Yellow Fever virus (YF) was isolated in $1927^{1}$ and is an endemic disease in tropical regions of South America and Africa, with thousands of new cases reported annually².

The causal agent of YF is an arbovirus and it is transmitted through the bite of an infected mosquito, the Aedes Aegypti in the urban areas ${ }^{3}$.

Prior to the advent of the vaccine, YF was one of the most feared human infections due to hepatitis, renal failure, hemorrhage, shock, and death in 20$50 \%$ of cases $^{2}$.

Still in the 1930s, two vaccines were created, and during their development 32 laboratory workers contracted the disease and $15 \%$ of them died' 1 .
Adverse effects have been observed since 1930 in about $20 \%$ of cases ${ }^{1}$. Severe effects include anaphylactic reaction, neurological disease and viscerotropic disease ${ }^{1}$ with an extensive list of contraindications to vaccination ${ }^{4}$.

Although reports of rashes secondary to the vaccine can reach $15 \%$, no images of such lesions were found in the literature.

\section{CASE PRESENTATION}

A healthy 18-month-old boy with no history of allergies received the YF vaccine isolated. After four days, erythematous papules appeared on palms, 


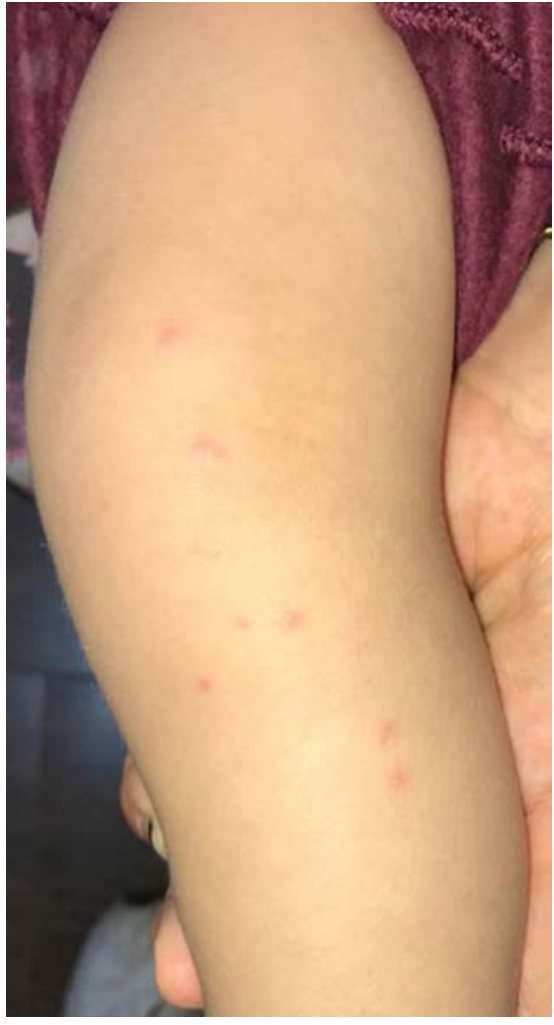

IMAGE 1. LESIONS ON THE LEG

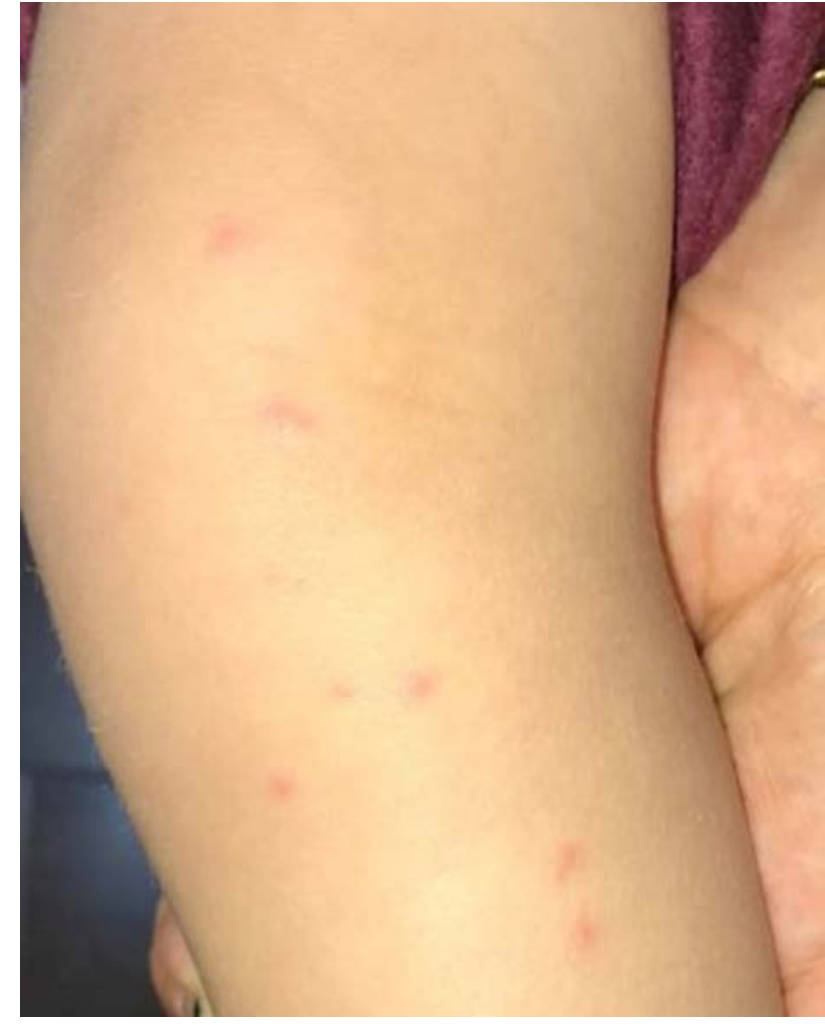

IMAGE 2. ISOLATED ERYTHEMATOUS PAPULES soles, trunk and limbs, including macular lesions on the conjunctiva (Image 1-2). There was no change in general condition, fever or pruritus. The lesions disappeared in three days without any treatment.

\section{DISCUSSION}

$\mathrm{YF}$ is an endemic disease in Brazil and the country has now the largest outbreak in the last decades, with a case fatality rate of $34.5 \%$ in $2017^{5}$.

The Brazilian vaccine is an attenuated live virus preparation of the 17DD strain lineage provided by the Oswaldo Cruz Foundation - FIOCRUZ ${ }^{6}$.

The reconstituted dose contains egg albumin, sucrose, sodium glutamate, sorbitol, bovine gelatin, erythromycin and kanamyci ${ }^{7}$. Cases of anaphylaxis may be secondary to the reaction to the egg protein or gelatin and have been reported in $1.8 / 100,000$ doses $^{2}$. However, a reaction to either component is possible, as well as to the latex from the vaccine vial lid'.

Currently, it is questioned if vaccination should be limited to people traveling to areas where the risk of YF exceeds the risk of serious adverse events following vaccination ${ }^{2}$.

A vaccine with inactive virus could reduce the risk of some of the adverse effects, especially of anaphylaxis, viscerotropic and neurotropic disease ${ }^{2}$.

\section{CONCLUSIONS}

We report a case of a toddler with cutaneous reaction to the 17D YF vaccine showing the skin lesions of this adverse reaction.

\section{RESUMO}

O vírus da febre amarela foi isolado em 1927, e a doença é considerada endêmica e epidêmica em regiões tropicais da América do Sul e África, com milhares de novos casos relatados anualmente.

Vários efeitos colaterais da vacina já foram relatados. Embora os relatos de erupções cutâneas secundárias à vacina variem de 0\% a 15\%, nenhuma imagem ou descrição detalhada das lesões foi encontrada na literatura. Aqui descrevemos a erupção de uma criança vacinada para viajar.

PALAVRAS-CHAVE: Exantema. Erupção por droga. Sistemas de notificação de reações adversas a medicamentos. Vacina contra febre amarela. 


\section{REFERENCES}

1. Monath TP. Review of the risks and benefits of yellow fever vaccination including some new analyses. Expert Rev Vaccines. 2012;11(4):427-48.

2. Hayes EB. Is it time for a new yellow fever vaccine? Vaccine. 2010; 28(51): 8073-6.

3. Thomas RE, Lorenzetti DL, Spragins W, Jackson D, Williamson T. Reporting rates of yellow fever vaccine 17D or 17DD-associated serious adverse events in pharmacovigilance data bases: systematic review. Curr Drug Saf. 2011;6(3):145-54.

4. Lindsey NP, Rabe IB, Miller ER, Fischer M, Staples JE. Adverse event reports following yellow fever vaccination, 2007-13. J Travel Med. 2016;23(5).
5. Brasil, Ministério da Saúde. Informe - № 43/2017. Monitoramento dos casos e óbitos de febre amarela no Brasil. [cited 2017 Aug 15]. Available from: http://portalarquivos.saude.gov.br/images/pdf/2017/junho/02/ COES-FEBRE-AMARELA---INFORME-43---Atualiza----o-em31maio2017.pdf

6. Centers for Disease Control and Prevention (CDC). Transmission of yellow fever vaccine virus through breast-feeding - Brazil, 2009. MMWR Morb Mortal Wkly Rep. 2010;59(5):130-2.

7. Fundação Oswaldo Cruz. Memento terapêutico 2014. Rio de Janeiro: Fiocruz; 2014. [cited 2017 Aug 15]. Available from: http://www.bio.fiocruz. br/images/stories/pdfs/outros/memento-terapeutico-2014.pdf 